\title{
Phytodentistry in Africa: prospects for head and neck cancers
}

\author{
Henry A. Adeola ${ }^{1,2^{*}}$ (D), Saheed Sabiu ${ }^{3}$, Raphael T. Aruleba ${ }^{4}$, Tayo A. Adekiya ${ }^{5}$, Anthonio O. Adefuye ${ }^{6}$, \\ Ogheneochuko J. Adefuye ${ }^{7}$ and Babatunji E. Oyinloye ${ }^{8}$
}

\begin{abstract}
Background: Orthodox dentistry has undergone significant changes in recent times with the introduction of various omics and molecular targeted therapies both at the experimental/trial and clinical implementation level. Although, significant milestones have been achieved in the molecular dentistry field in the past decade, there remains a dearth of application of phytopharmacological innovation in personalized and targeted therapies for dental diseases.

Main body: From time immemorial, plant products have long been an integral aspect of dental practice ranging from chewing sticks/herbal kinds of toothpaste to dental/impression materials. The current era of precision medicine seeks to apply a multipronged molecular and bio-computational approaches to solve fundamental medical problems that have hitherto remained difficult. Remarkable changes in the molecular/omics era, have transformed empirical therapies into personalized/individualized ones. Furthermore, the combinatorial application and the widespread introduction of high-throughput molecular tools such as pharmacogenomics, phytopharmacology, metabolomics, mathematical modelling, and genetic engineering inter alia, has tremendously improved the diagnostic and therapeutic landscape of medicine. Additionally, the variable molecular epidemiology of diseases among different population and emerging molecular evidence warrants the use of customized novel theranostic techniques. Unfortunately, the footprint of such emerging application is sparse in dental diseases such as maxillofacial cancers.
\end{abstract}

Conclusion: Hence, this review seeks to evaluate the potential application of phytopharmacological approaches to head and neck cancers in a resource-limited environment, such as Africa.

Keywords: Phytopharmacology, Cancer, Dental pathology, Molecular mechanism, Dentistry, Structural biology, Phytodentistry

\section{Introduction}

Healing with plants is as old as mankind itself. The link between man and his quest for treatments in nature dates back to ancient times when anecdotal evidence was garnered from monuments, written documents, and

\footnotetext{
* Correspondence: henry.adeola@uct.ac.za

'Division of Dermatology, Department of Medicine, Faculty of Health

Sciences and Groote Schuur Hospital, University of Cape Town, Observatory, Cape Town 7925, South Africa

${ }^{2}$ Department of Oral and Maxillofacial Pathology, Faculty of Dentistry, University of the Western Cape and Tygerberg Hospital, Cape Town, South Africa

Full list of author information is available at the end of the article
}

even original plant medicines [1]. Plants have been used for prophylaxis and healing of diverse diseases before the advent of iatrochemistry in the sixteenth century [2]. This has been particularly showcased in Africa since ancient times, with the widespread integration of medicinal plants in the indigenous healthcare practices.

Africa is known as the cradle of mankind and it possess a rich cultural and biological diversity [3]. Phytopharmacology and phytomedicine has been in Africa for centuries and is considered the most widely used method for healing practices. Phytomedicine in Africa employs a holistic approach which considers both the 
healing of the mind and the body. The psychological basis of diseases is first addressed before medical regimens (typically-derived) are provided to cure the disease [4]. There are 3 major reasons why there is a sustained interest in African phytomedicine, viz: poor access to western allopathic medicines due to lack of financial resources, manpower and health infrastructure; lack of efficacious modern medicine for some illnesses which are typical to Africa; and the rich diversity of the African flora and fauna [5]. In addition, detrimental side effects and reducing efficacy of synthetic western drug have reawakened the attention of researchers globally to natural medicine (particularly from Africa), in recent times [6]. Such efforts have revealed a plethora of African plants that have potent pharmacological effects and hence are good candidates for the development of lead compounds in the drug discovery pipelines.

Phytomedicine is globally sought after as a means primary healthcare provision for ca. 3.5-4.0 billion people, and a significant percentage of this involves the use of plant-derived decoction and medicines [7]. More so, using medicinal plants has been the most commonly practised traditional medicine system across the African continent. Medicinal plants are readily accessible health resources for many African communities [8]; and they are often more preferred over conventional medicine [9]. Information, treatment and counselling, garnered from traditional healers are presented to patients and their families in a more indigenous and cultural manner [10]. As a matter of fact, Africa is highly endowed with plant biodiversity constituted by ca. 40,000 to 45,000 plant species that can be potentially developed; and close to 5000 of these are currently medically applied according to pharmacopoeia information $[11,12]$. The fact that Africa is situated tropically with subtropical climate favours an adaptive accumulation of secondary plant metabolites [13]. Strong ultraviolet rays from tropical sunlight and pathogenic microbes, such as fungi, bacteria, and viruses are additional factors that promote the accumulation of plant chemopreventive in relatively higher concentrations compared to northern hemisphere flora. A Dorstenia (Moraceae) study reported Dorstenia mannii Hook.f, which is perennial to the tropical central African rain forest to contain more biologically active components as compared to other related species [14].

Hence, accurate documentation of indigenous African plant medicinal systems has become essential, to mitigate the continuous erosional and anthropogenic loss of natural habitats. It has been reported that even though Africa has close to 216 million hectares of forest, she unfortunately also has one of the highest levels of deforestation globally (ca. of $1 \%$ per annum) [15]. Against this backdrop, limited healthcare resources and high burden of head and neck cancer [16] warrants a more extensive use of phytopharmacological compounds in the African dental setting. This review focuses mainly on the potential beneficial effect of medicinal plant bioactive compounds, for the management of cancers (particularly head and neck), in the context of Africa.

\section{Benefits and direction of phytopharmacology in the African setting}

Nature is the most effective source of naturally occurring herbs that are a reservoir of pharmacologically active phytochemicals and phytomedicine. Their easy accessibility, affordability, safety and efficacy have hugely culminated in their success against some severe diseases and reliability among the users [17]. Indeed, conventional medicine has its roots in medicinal plants, and it is likely that many novel remedies will still be developed and commercialized in the future from the African biodiversity, as it has been till now, by following the leads provided by traditional knowledge and experiences [4, 12]. Over the last decade in Africa, there has been enormous rise in medicinal plants-derived products in terms of interest and use [10]. Prior to this time, what used to be the exclusive domain of health food and speciality stores has now gained considerable popularity into the mainstream market as evident by their impressive sale at some of the major retail outlets, their publicity, and advertising in the media, and due to the entry of various pharmaceutical giants in the area of phytomedicines. Also, despite that dosage standardization, exact mechanism of action and safety issues could still be identified as factors militating against the use of many of the medicinal plants within the African setting and beyond, the World Health Organization (WHO, 2000) has encouraged African member states to promote and integrate traditional medical practices in their health system.

Unlike the first and second generation phytopharmacological advancements in Africa, the third and indeed the current generation is poised to encourage formulations based on well-controlled double-blind clinical and toxicological studies to improve the quality, stability, safety and efficacy of such formulations [8]. Also, contrary to the argument that appreciation of phytomedicine in Africa is linked to cultural and economic reasons, emerging evidence from clinical and experimental data strongly suggests their therapeutic efficacy against several diseases including diabetes, malaria, sickle-cell anaemia, Human Immunodeficiency Virus/ Acquired Immune Deficiency Syndrome (HIV/AIDS), cancer, dental disease, stroke, ulceration, Alzheimer's disease, Parkinson's disease, Huntington's disease, and microbial infections etc. [6, 10, 15, 18-23]. Furthermore, through appreciation of phytopharmacology, many African phytomedicines have become well known in the international markets and several of them including a 
Cameroonian plant (Ancistrocladus abbreivatus) with anti-HIV/AIDS potential, Elaeis guineensis, Agava sisalana, Tamarindus indica, Zingiber officinale, Capsicum annum, Phytostigma venenosum, Catharantus roseus, Rauvolfia vomitoria, Chrysanthemum cinerariifolium, and Prunus africana etc. with diverse pharmacological activities are exported to other parts of the world and contributing to the economic development of the region [8].

In spite of the tremendous efforts of African phytopharmacologists to decipher African ailments and proffer lasting solutions, gaps still exist and there is a need for a more holistic, rational, and generally acceptable strategy to explain the efficacy of medicinal plants and their mechanisms of action. In view of this, the concept of "-omics" (metabolomics, proteomics, transcriptomics, and genomics etc.) as currently being explored, could find relevance and may provide useful data supporting the efficacy of phytotherapy. Ultimately, this will annihilate the mainstream issues against the advancement of phytopharmacology in Africa and making it one of the focal contributors to research advancement and economic development of the continent. Research in this direction holds promising scope for discovering precise and novel therapeutic products in Africa and beyond.

\section{Phytopharmacology and head and neck cancer}

Over the years, cancer continues to impose a heavy burden on public health and presents a challenge to science. Globally, cancer is a leading cause of death; it is believed that the growth and aging of the population will increase cancer burden, especially in Africa, Asia, Central and South American, where approximately $70 \%$ of the world's population resides [24, 25]. This disease has been labelled as a global menace and kills more people than AIDS, tuberculosis and malaria combined [26, 27]. As documented by Ferlay et al., [25], head and neck cancer accounts for over 600,000 cases yearly, with $40 \%-50 \%$ mortality. In fact, over half of all sufferers will eventually die of the disease [28]. The tumours arise in the epithelial cells of the mucosal linings of the oral cavity, nasal cavity, oropharynx, pharynx and larynx, most of which are squamous cell carcinoma of the head and neck $(\mathrm{SCCHN})$ [29]. In addition to the synergistic effect of tobacco and alcohol, which is the most important risk factors for SCCHN, infection with human papillomavirus (HPV) has also been implicated in the pathogenesis of SCCHN [30]. Besides these exogenous risk factors, Fanconi anaemia and a more general genetic susceptibility may cause SCCHN [30,31]. The choice of treatment of SCCHN is largely dependent on the stage and location of tumour. The stage of the tumour is determined by the extent of the tumour, presence of lymph node metastases and distant metastases. More so, correct staging with the aid of computed tomography $(\mathrm{CT})$ or magnetic resonance imaging (MRI) by a head and neck surgeon is of paramount importance in therapeutic decision making [29]. Current treatment options include surgery and radiotherapy. However, recurrent and metastatic cancer is generally untreatable. As reviewed by Forastiere et al [32], great strides have been made in the treatment of head and neck cancer, but existing treatment options are still faced with one or more challenges. Noteworthy is the invasiveness of surgical methods and chemotherapeutic agents toxicity; both usually accompanied with severe side effect on non-target cells. Certainly, there is an unmet need for development or exploration of alternative and complementary treatment options. Based on extensive literature search, it could be opined that the use of monotherapy and surgery, as often the case, might not be exhaustive and efficacious treatment for cancer. Consequently, an important area researchers and clinicians should focus SCCHN investigations into is the application of phytopharmacology in managing, curing or ameliorating treatment-induced toxic effects.

Medicinal plants are made up of various chemical constitutes that works independently, supplement or in synergy to improve health [3]. These natural plant-derived medicines that have been used in the remedy of various health problems, have a safe profile, they are gentle, cost-effective and easily accessible; and this has encouraged self-medication without consulting a medical practitioner [33-36].

While the exact molecular mechanisms by which medicinal plants mediate their chemo-preventive (cancer preventive) properties are still unclear, it has been suggested that the mechanism of medicinal plant-derived chemoprevention may be due to the presence of phytocompounds (which may work in a synergistic/combinatorial manner) with strong antioxidant and antiproliferative properties [37]. Similarly, it has been reported that the chemical constituents of medicinal plants can induce apoptosis, possess anti-inflammatory, anti-hormonal and immune-enhancing effect. They can also induce cell cycle arrest, cell differentiation, suppression of cellular proliferation and angiogenesis; as well as inhibiting secondary modification and development of the neoplastic cells [38].

It has been suggested that phytocompounds can carry out their antioxidant activities by lowering free radical production through metal chelation and free radical scavenging [22, 39]. In addition, phytocompounds can reduce mitochondrial damage and fission, thereby enhancing the electron transport chain and oxidative phosphorylation [39]. The transcription factor nuclear erythroid 2-related factor 2 (Nrf2) can be activated and translocated to the nucleus, by polyphenols (e.g., hydroxytyrosol), where it can transactivate antioxidant enzymes and phase II genes, by binding antioxidant response elements promoters [38, 39]. Anti- 
inflammatory effect of phytocompounds have been linked to downmodulation of proinflammatory cytokines, prostaglandins, NF- $\mathrm{kB}$, nitric oxides, as well as inducible NO synthase (iNOS) and other proinflammatory genes [39]. Furthermore, hydroxytyrosol has been found to influence cellular energetics by increasing the expression of respiratory chain mitochondrial complexes (I-V) and overall mitochondrial function [39].

\section{Plant-derived anticancer agents}

For centuries now, plants have been recognized in the treatment of cancer. More so, several bioactive compounds isolated from plants are presently undergoing clinical trials or preclinical trials for cancer $[5-7,9]$. Imperatively, present and future studies are expected to explore phytomedicine preparations to offer proper treatment and management of various forms of cancers. In this context, we have reviewed some phytomedicinal drugs and compounds that have shown remarkable activities against SCCHN.

\section{Herbal-derived drugs with anti-cancer properties}

Vinca alkaloids (VA) are important anticancer drugs obtained from the Madagascar periwinkle plant [40]. Currently, the four main semi-synthetic derivatives of VA in use against cancer are vinorelbine, vindesine, vinfosiltine and vinovelbine, they are used alone or complementing other phytochemical compounds to fight a large number of cancers [41]. As documented by Safarzadeh et al. [42], the mechanism VA uses in exacting their anti-cancer effect is by the disruption of microtubule function through tubulin interaction and destruction resulting to arrest and termination of cell division. Regimens able to impede the microtubule assembly can arrest cell cycle at metaphase, hence leading to cell death via apoptosis [43]. Added to their anti-cancer properties, VA has been used in the treatment of high blood pressure [40] and diabetes [44]. On the basis of the promising activities shown by vinorelbine in head and neck cancer, Gebbia et al., [45] tested its activity in combination with cisplatin. It was shown that the combination is effective both in patients of recurrent and untreated unresectable patients. When co-administered with cisplatin and 5fluorouracil, vinorelbine has shown complete responses in SCCHN [46]. Another study using vinblastine combined with monoclonal anti-flk-1 (DC101) in the treatment of poor prognosis-related human neuroblastoma cells, grown in Severe combined immunodeficiency (SCID) mice showed that low doses of vinblastine combined with DC101 achieved full and sustained regression of established cancer, without subsequent host toxicity [47].
Berberine (BBR), a natural isoquinoline quaternary alkaloid is well known for its immense application in the remedy of various maladies in the traditional ayurvedic literature [48]. Based on this, researchers have explored the cytotoxic activities of this compound against cancer. In hepatocellular carcinoma cells, BBR causes cancer cell death by simultaneous induction of autophagy and apoptosis [49]. BBR caused an increase in Bax expression and a decrease in mitochondrial membrane permeability, leading to mitochondrial apoptosis in MHCC97-L and HepG2 cells [49]. Accumulative evidence using this isoquinoline alkaloid has demonstrated its potential application as a chemotherapeutic agent for the management of SCCHN. For example, in an in vitro study using human tongue cancer SCC-4 cell line, it was shown that BBR stimulated the expression of Apaf- 1 which resulted to increased activation of caspase-3, hence causing apoptosis [50]. More recently, another work was done on $\mathrm{FaDu}$ head and neck squamous cell carcinoma cells, demonstrated that BBR triggered upregulation of apoptotic ligands like Tumour Necrosis Factor (TNF)- related apoptosis-inducing ligand and FasL, activated caspase-8,7 and -3 and adenosine diphosphate (ADP) ribose polymerase [51]. Still, in the same context, inhibition of the migration and invasion of human SCC-4 tongue squamous carcinoma cells by BBR was reported by Ho et al., 2009b. In the study [52], the inhibition of Matrix Metalloproteinase (MMP)-2 and - 9 in human SSC-4 cells was mediated by thep-JNK, p-ERK, p-p38, IkK and NF- $k$ B signalling pathways. Remarkably, BBR anti-cancer effect increased significantly when co-administered with evodiamine [53], arsenic trioxide [54] and cisplatin [55].

Another vital addition to the plant-derived anti-cancer drug armamentarium is the taxanes. Currently considered as the most efficacious anti-cancer agent, taxanes act by interfering with the microtubules and has a crucial role in cell division [41, 42]. Paclitaxel (taxol) is utilized as therapeutic agent in ovarian, Kaposi Sarcoma, lung cancer, SCCHN and breast cancer [56]. Studies have targeted molecular treatment against epidermal growth factor receptor (EGFR) since it has shown to be promising in adjuvant therapy for head and neck cancer. The therapeutic efficacy of EGFR blockage with paclitaxel combined with PKI166 against human oral cancer increased programmed cell death in vitro and growing orthotopically in nude mice [57]. Also, administration with cisplatin and fluorouracil causes significant survival benefits with tolerable toxicity for patients with locally advanced head and neck cancer [58].

\section{Herbal-derived compounds with anti-cancer activities}

Upregulation of both proinflammatory and proangiogenic factors are implicated in aggressive tumour growth and decline in the health of sufferers of SCCHN. 
Curcumin; a phenolic compound derived from rhizome is a potent inhibitor of cell proliferation and inducer of programmed cell death in SCCHN by downregulating IкB $\alpha$ kinase (IKK) mediated NF-K $\beta$ activation $[59,60]$. Moreover, the cytotoxic effects of doxorubicin and its analogues involve NF-K $\beta$ signalling pathway, therefore, curcumin increases the efficacy of doxorubicin by impeding NF-K $\beta$ signalling pathway [42].

More recently, grape seeds proanthocyanidins (GSPs) has been gaining interest as an anti-SCCHN agent. GSPs has the ability to hinder the SCCHN cell invasion by targeting the EGFR expression, as well as halting the transition from epithelial to mesenchymal cells [61]. This polyphenolic compound prevents cancer initiation with no toxicity in animal models and normal human bronchial epithelial cells $[62,63]$.

Park et al., [64] studied Licochalcone-A purified from Glycyrrhiza inflata roots and found out that it significantly increased death of pharyngeal squamous carcinoma FaDu cells with activated apoptotic factors and Poly (ADP-ribose) polymerase (PARP) in a caspasedependent manner and decreased anti-apoptotic factors. Lee et al. (2008) [65] and Cho et al. (2014) [66] have also lent credence to cytotoxic activity of Licochalcone-A.

Similarly, resveratrol, a phytoalexin found in red grape skin, has been shown to cause cancer cell death via different mechanisms such as mitotic catastrophe, apoptosis and autophagy [67].

Overall, the scope of phytopharmacology in the treatment and management of cancer is imminent and could not be undermined. In fact, when employed for SCCHN therapy, phytopharmacology has great potentials in minimizing side effects caused by chemoradiotherapy and surgery, at the same time increasing survival rates and reducing recurrence/ unresectable cancer rates. Although there are still many questions to be answered in the field of phytomedicine, such as efficacy and safety parameters of herbal products, the use of plant products in head and neck cancer treatment holds promising grounds and warrants continuous research adventures. A list of selected compounds of pharmacological significance in head and neck cancer is presented in Table 1.

\section{Phytopharmacology and structural biology}

The understanding of the structure and function of proteins is an important phenomenon in deciphering the molecular basis of diseases. Hence, structural biology is a research field of study that focuses on determining the function, molecular mechanisms and structure of biological molecules or proteins. The field has aided the understanding of basic molecular mechanisms in diseases such as designing of new pharmaceutical products, as well as understand drug action $[68,69]$. Thus, structural phytopharmacology is an approach used in designing and developing novel drugs to target and inhibit proteins or biological molecules through the means of medicinal plants and their products.

Cost and unavailability of orthodox drugs and health care, as well as several side effects associated with the use of synthetic drugs, makes using phytocompounds a potentially valuable and practical options [70]. Therefore, the exploration of pharmacologically active substances found in plants has been a better alternative in medical applications, this is due to the presence of several complex chemical substances of diverse composition which are found as secondary metabolites (phytonutrients or phytochemicals) such as flavonoids, terpenoids, alkaloids, saponins, polyphenols, lignans, carotenoids, indoles, isoflavones among others [71]. Globally, functional bioactive compounds (FBCs) of plants source or plantderived compounds have been significant sources of therapeutic drugs for humans and animals in treatment

Table 1 Selected phytocompounds of therapeutic importance against head and neck cancer

\begin{tabular}{|c|c|c|}
\hline Phytocompound & Mechanism of action & reference \\
\hline Vinca alkaloids & $\begin{array}{l}\text { Disrupts microtubule function through tubulin interaction and destruction resulting } \\
\text { Stalls cell division and facilitate apoptosis }\end{array}$ & $\begin{array}{l}{[42]} \\
{[43]}\end{array}$ \\
\hline Berberine & $\begin{array}{l}\text { cancer cell death by simultaneous induction of autophagy and apoptosis } \\
\text { caused an increase in Bax expression and a decrease in mitochondrial membrane permeability, leading to } \\
\text { mitochondrial apoptosis }\end{array}$ & [49] \\
\hline Taxanes & $\begin{array}{l}\text { Interferes with the microtubules and cell division } \\
\text { Blocks epidermal growth factor receptor (EGFR) }\end{array}$ & $\begin{array}{l}{[41,42]} \\
{[57]}\end{array}$ \\
\hline Curcumin & $\begin{array}{l}\text { Potent inhibitor of cell proliferation and inducer of programmed cell death in SCCHN by downregulating } \\
\text { IKBa kinase (IKK) mediated NF-K } 3 \text { activation }\end{array}$ & {$[59,60]$} \\
\hline $\begin{array}{l}\text { Grape seeds } \\
\text { proanthocyanidins (GSPs) }\end{array}$ & $\begin{array}{l}\text { Has the ability to hinder the SCCHN cell invasion by targeting the EGFR expression, as well as halting the } \\
\text { transition from epithelial to mesenchymal cells }\end{array}$ & [61] \\
\hline Licochalcone-A & $\begin{array}{l}\text { Significantly increased death of pharyngeal squamous carcinoma FaDu cells with activated apoptotic } \\
\text { factors and PARP in a caspase-dependent manner and decreased anti-apoptotic factors }\end{array}$ & [64-66] \\
\hline Resveratrol & Cause cancer cell death via mitotic catastrophe, apoptosis and autophagy & [67] \\
\hline
\end{tabular}


of diverse diseases [72]. FBCs possess numerous chemical and structural properties such as the ability to interact or binds and stimulate a specific molecular receptor or protein and this has led to several important discoveries. For instance, gingerol, resveratrol, phytosterol, epigallocatechin, myricetin, among others may directly influence several molecular signal transduction pathways such as cell migration/proliferation, metabolic disorders, inflammation cascade, and oxidative stress which are implicated in the development of different noncommunicable diseases [73-75], such as cancer.

\section{An overview of phytochemical interactions and stimulations of molecular receptors}

Plant-based drugs have been elucidated with therapeutic activity in the treatment of diverse diseases due to their ability to stimulate or interact with biological molecules or proteins which are responsible for such diseases. Example of such plant-based drugs approved for therapeutic use in the treatment of diseases are artemisinin (Artemisia annual), arglabin (Artemisia glabella Kar. and Kir), capsaicin (Capsicum annum), colchicine (Colchicum spp), cannabidol dronabinol (Cannabis sativa). Others are Solamargine (Solanum spp), masoprocol (Larrea tridentata), galanthamine (Galanthus caucasicus), paclitaxel (Taxus brevifolia), ingenol mebutate (Euphorbia peplus), omacetaxine mepesuccinate (Cephalotaxus harringtonia).

In 2011, Yang et al., [76] investigated the apoptotic mechanisms of celastrol, a major biologically active compound isolated from Tripterygium regelii on human breast cancer cells line (MCF-7). It was shown that celastrol inhibited cell growth remarkable in time- and dose-dependent manners. It was further discovered that the compound induced the formation of apoptotic bodies, accumulation of sub-G1 deoxyribonucleic acid (DNA), and condensation of nuclear in MCF-7 cells [76]. Also, celastrol stimulated the activation of caspase$7,-8$ and -9 , and upregulated the activation of caspase family proteins, cleavage of PARP, release of cytochrome $\mathrm{c}$ and AIF, and mediated the cleavage of caspase-8. More so, it was revealed that celastrol increased the upregulation of pro-apoptotic Bax protein and downregulated the expression of the anti-apoptotic $\mathrm{Bcl}-2$ protein. All these aforementioned activities of celastrol depict its inhibitory role in the proliferation of human breast cancer cells [76]. In 2016, Pan and co-workers [77] evaluated the phytopharmacological activities of triptonide, a compound derived from Tripterygium wilfordii on telomerase reverse transcriptase (TERT) protein, an enzyme responsible for the malignant progression and immortalization of acute myeloid leukemia (AML) and HPV-induced oral cancers. It was observed in their mechanistic studies that the derived compound totally induces senescence by suppressing the transcription of TERT which resulted in apoptosis in cultured AML cell lines (U937 and HL-60 AML), and inhibited colony formation as well as the growth of leukemia by suppressing oncogenic c-Myc. Also, the compound promotes the proapoptotic gene which encodes for DNA damageinducible transcript 3 and stimulates the transcription of genes (p16 and p21) which are senescence-promoting gene. In addition, it was shown that triptonide completely suppressed the formation of human leukemia cell without posing any observable toxicity effects in mice in a xenograft model [77].

In another related study by Tan and colleagues [78], the identification and inhibitory activities of 56 novel naturally occurring phytochemicals were investigated on the efflux transporter breast cancer resistance protein (ABCG2/BCRP); a multidrug resistance protein in breast cancer. In the study, the results of non-flavonoid phytochemicals investigated (ellagic acid, berberine, oleanolic acid, celastrol, ursolic, limonin and sinapic acid) showed significant increase in inhibitory activities of the phytochemicals compounds on ABCG2-mediated transport enzyme in membrane- and cell-based transport inhibition analyses. Other novel flavonoid phytochemical compounds identified to inhibit ABCG2 protein in the study were myricetin, pinocembrin, chrysoeriol, quercitrin, laricitrin, tamarixetin, $3^{\prime}, 4^{\prime}, 5^{\prime}$-trimethylether, tricetin $3^{\prime}, 4^{\prime}, 5^{\prime}$-trimethylether and tricetin. Thus, the inhibitory activities of these phytochemical compounds on ABCG2 propose a background for further examination of ABCG2-modulated phytochemical bioavailability and multidrug resistance in breast cancer [78]. In a similar study in 2013, Perez and colleagues [79] investigated the inhibitory effects of daidzein and genistein, isoflavones found in soy on ABCG2 by reducing the plasma and milk levels of danofloxacin in sheep. It was observed that both isoflavones effectively inhibited the in vitro movement of the drug in BCRP-transduced MDCK-II cells. This predicted that the soy-enriched diet can modify the in vivo milk secretion of danofloxacin, a BCRP substrate in sheep [79].

A study by Biswas and co-workers [80], evaluated the inhibitory activities of phytochemical compounds on multidrug resistance in cancer and proposed the mechanisms by which standardized berry extracts inhibit the endothelial cell tumour growth for hemangiomas. The study further established that natural berry extracts considerably inhibited the actions of multidrug resistance protein-1 (MRP-1) in EOMA cells when compared with controls. The inhibition of MRP-1 resulted in apoptotic tumour cell death via the accumulation of oxidized glutathione (GSSG) in the nucleus of EOMA cells where there is hyperactiveness of NADPH oxidase thereby causing angiogenesis pathology [80]. 


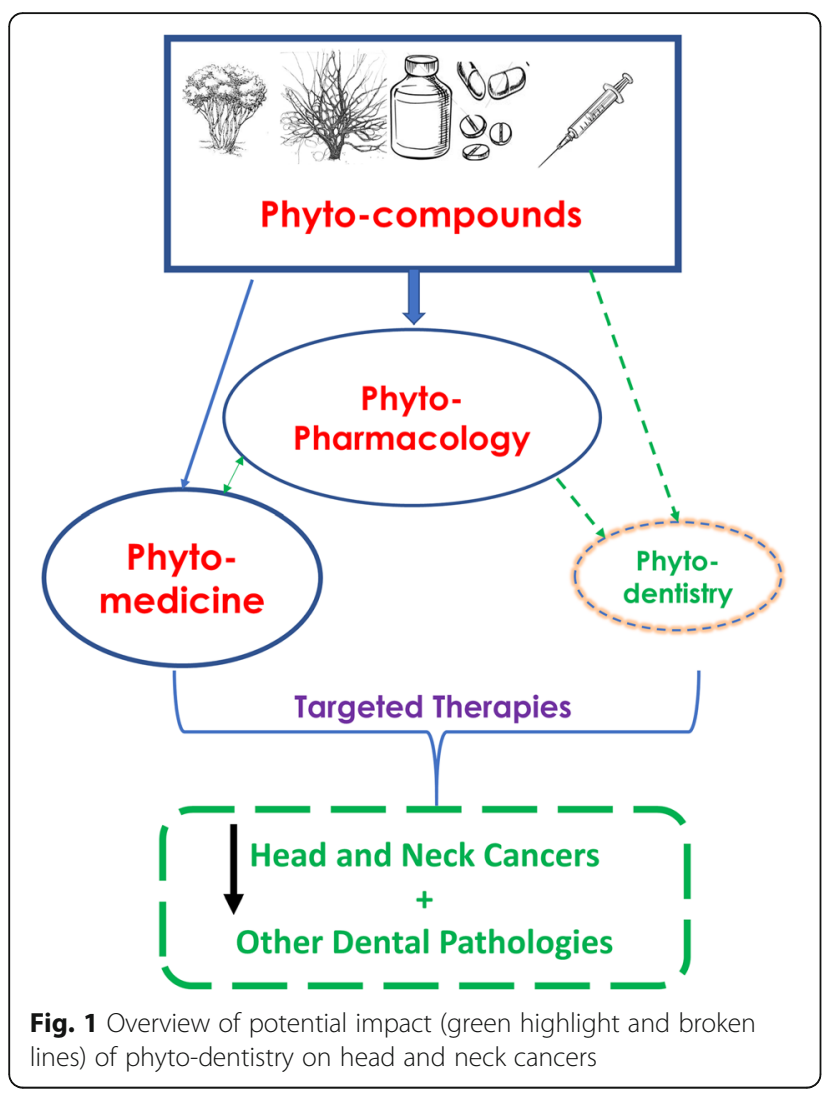

Role of computational biology in phytopharmacology

In recent time, computational biology has given insight to target proteins which are functionally and structurally conserved in diseases using medicinal plant phytochemicals. This is due to higher cost and time involved in conventional methods of screening for new drugs and new chemical entities (NCEs) with low toxicity and high pharmacological response. In 2019, Oyinloye and co-workers [81] employed this approach in proposing the regulation of glucose consumption by cancerous cells via the inhibition of glucose transporter-4-protein (GLUT4) by selected phytochemical compounds from Solanum xanthocarpum. Their study revealed that out of seven phytochemical compounds selected from Solanum xanthocarpum, stigmasterol glucoside showed higher binding affinity to GLUT4 when compared to the control. Also, stigmasterol glucoside fulfils oral drugability of rule of five and conversely predicted to be non-mutagen and safe for the body. Added to this, computational biology has also been used in screening for potent pan-serotype phytochemical compounds as inhibitors for conserved non-structural dengue virus protein targets (NS1, NS2B/NS3 and NS5) [82], as well as the molecular mechanism and pharmacotherapeutics activity of phytocompounds against breast cancer drug-protein target (aromatase) [83].

\section{Conclusion}

The use of medicinal plants in the treatment of diseases (ethnomedicine) is an ancient tradition that has coexisted with human habitation [84]. Overall, several phytocompounds have been demonstrated to be of therapeutic importance, but fewer numbers have been brought into clinical dental utility (Fig. 1). Persistent rise in the incidence of oral cancer has long been recognised as a major public health problem worldwide [85], and locally in Africa [16]. Phyto-constituents derived from medicinal plants have proven to be an important source of therapeutically useful compounds with the potential of being developed into new and potent pharmaceuticals [85]. Phyto-dentistry, the use of plants and their products in dental practice has long been documented, however, plant products have only been marginally used in dental material, as well as an adjunct therapy in dental practice [84]. Emerging omics fields and development of state-of-the-art omics instrumentation is expected to accelerate the uptake and application of phytodentistry to treating head and neck cancers, and indeed other dental diseases. Hence, this review heralds a wider coverage of phytodentistry for improved, personalized and costeffective treatment of dental diseases in Africa.

\section{Abbreviations}

AML: Acute myeloid leukemia; BBR: Berberine; CT: Computed tomography; DNA: Deoxyribonucleic acid; EGFR: Epidermal growth factor receptor; FBCs: functional bioactive compounds; GLUT-4: Glucose transporter-4-protein; GSP: Grape seeds proanthocyanidins; HIV/AIDS: Human immunodeficiency virus/acquired immune deficiency syndrome; HPV: Human papillomavirus; MRI: Magnetic resonance imaging; MRP-1: Multidrug resistance protein-1; PARP: Poly (ADP-ribose) polymerase; SCCHN: Squamous cell carcinoma of the head and neck; SCID: Severe combined immunodeficiency; TERT: Telomerase reverse transcriptase; VA: Vinca alkaloids; WHO: World health Organization

\section{Acknowledgements}

HAA would like to thank the South African Medical Research Council (SAMR C) for a mid-career scientist and self-initiated research grants and the South African National Research Foundation (NRF) for a research development grant for rated researchers.

\section{Code availability \\ Not applicable.}

\section{Authors' contributions}

HAA conceptualized, designed, prepared and critically revised the manuscript, table and Fig. SS, RTA, TAA, AOA, OJA and BEO were involved in the design and critical intellectual revision of the paper. All authors were involved in preparing the manuscript and had final approval of the submitted and published versions.

\section{Funding}

Not applicable.

\section{Availability of data and materials}

Data sharing not applicable to this article as no datasets were generated or analysed during the current study.

Ethics approval and consent to participate Not applicable.

Consent for publication

All authors have given consent for publication. 


\section{Competing interests}

The authors declare that they have no conflict of financial or non-financial interest.

\section{Author details}

'Division of Dermatology, Department of Medicine, Faculty of Health Sciences and Groote Schuur Hospital, University of Cape Town, Observatory, Cape Town 7925, South Africa. ${ }^{2}$ Department of Oral and Maxillofacial Pathology, Faculty of Dentistry, University of the Western Cape and Tygerberg Hospital, Cape Town, South Africa. ${ }^{3}$ Department of Biotechnology and Food Technology, Durban University of Technology, Steve Biko Campus, Steve Biko Road, Berea, Durban 4001, South Africa. ${ }^{4}$ Department of Molecular and Cell Biology, Faculty of Science, University of Cape Town, Cape Town 7701, South Africa. ${ }^{5}$ Wits Advanced Drug Delivery Platform Research Unit, Department of Pharmacy and Pharmacology, School of Therapeutic Science, Faculty of Health Sciences, University of the Witwatersrand, 7 York Road, Parktown, Johannesburg 2193, South Africa. ${ }^{6}$ Division Health Sciences Education, Office of the Dean, Faculty of Health Sciences, University of the Free State, Bloemfontein, South Africa. ${ }^{7}$ Division of Virology, School of Pathology, Faculty of Health Sciences, University of the Free State, Bloemfontein, South Africa. ${ }^{8}$ Phytomedicine, Biochemical Toxicology and Biotechnology Research Laboratories, Department of Biochemistry, Faculty of Sciences, Afe Babalola University, P.M.B 5454, Ado Ekiti 360001, Nigeria.

\section{Received: 17 July 2020 Accepted: 2 February 2021}

Published online: 05 February 2021

\section{References}

1. Stojanoski N. Development of health culture in Veles and its region from the past to the end of the 20th century. Macedonia: Society of science and art; 1999. p. 13-34

2. Kelly K. History of medicine. New York: Facts on file; 2009. p. 29-50.

3. Gurib-Fakim A. Medicinal plants: traditions of yesterday and drugs of tomorrow. Mol Asp Med. 2006;27(1):1-93.

4. Gurib-Fakim, A., Brendler,T., Phillips L. D., Eloff, L. N., (2010). Green gold-success stories using southern African plant species. AAMPS Publishing, Mauritius

5. Sawadogo WR, Schumacher M, Teiten MH, Dicato M, Diederich M. Traditional west African pharmacopeia, plants and derived compounds for cancer therapy. Biochem Pharmacol. 2012;84(10):1225-40.

6. Sabiu S, Ajani EO, Ajao AA, Sunmonu TO, Ibraheem AS, Ibrahim R, Mustapha $\mathrm{H}$, Adekeye AO. Biomembrane stabilization and antiulcerogenic properties of aqueous leaf extract of Gossypium barbadense L.(Malvaceae). Beni Suef Univ J Basic Appl Sci. 2017;6(4):301-9.

7. Pan SY, Zhou SF, Gao SH, Yu ZL, Zhang SF, Tang MK, Sun JN, Ma DL, Han YF, Fong WF, Ko KM. New perspectives on how to discover drugs from herbal medicines: CAM's outstanding contribution to modern therapeutics. Evid Based Complement Altern Med. 2013:2013:1-25.

8. Okigbo RN, Mmeka EC. An appraisal of phytomedicine in Africa. Curr Appl Sci Technol. 2006:6(2):83-94.

9. Raliat AA, Saheed S, Abdulhakeem SO. Pteleopsis suberosa Engl. and Diels (Combretaceae) aqueous stem bark extract extenuates oxidative damage in streptozotocin-induced diabetic Wistar rats. Pharmacognosy J. 2019;11(1): 183-90.

10. Mahomoodally MF. Traditional medicines in Africa: an appraisal of ten potent African medicinal plants. Evid Based Complement Altern Med. 2013; 2013:1-15.

11. Geldenhuys CJ, van Wyk BE. Indigenous biological resources of Africa. In: Baijnath $H$, Singh $Y$, editors. Rebirth of science in Africa: a shared vision for life and environmental sciences. Contributions to the African Renais-science conference, Durban, 25-29 March 2002. Hatfield: Umdaus Press; 2002. p. 116-32.

12. Moyo M, Aremu AO, Van Staden J. Medicinal plants: an invaluable, dwindling resource in sub-Saharan Africa. J Ethnopharmacol. 2015;174:595606.

13. Manach C, Scalbert A, Morand C, Rémésy C, Jiménez L. Polyphenols: food sources and bioavailability. Am J Clin Nutr. 2004;79(5):727-47.

14. Abegaz BM, Ngadjui BT, Folefoc GN, Fotso S, Ambassa P, Bezabih M, Dongo E, Rise F, Petersen D. Prenylated flavonoids, monoterpenoid furanocoumarins and other constituents from the twigs of Dorstenia elliptica (Moraceae). Phytochemistry. 2004;65(2):221-6.
15. Gurib-Fakim A, Mahomoodally MF. African Flora as potential sources of medicinal plants: towards the chemotherapy of major parasitic and other infectious diseases: A review. Jordan J Biol Sci. 2013;147(624):1-8.

16. Adeola HA, Afrogheh AH, Hille JJ. The burden of head and neck cancer in Africa: the status quo and research prospects. S Afr Dent J. 2018;73(8):47788.

17. Sabiu S, Ajani EO, Abubakar AA, Sulyman AO, Nurain IO, Irondi EO, Abubakar YA, Quadri MF. Toxicological evaluations of stigma maydis (corn silk) aqueous extract on hematological and lipid parameters of Wistar rats. Toxicol Rep. 2015;2:638-44.

18. Sofowora, A. (1993). Medicinal plants and traditional medicine in Africa.2nd edition. Spectrum books limited, sunshine house, Ibadan, Nigeria, 289.

19. Boyd MR, Hallock YF, Cardellina JH, Manfredi KP, Blunt JW, McMahon JB, Buckheit RW Jr, Bringmann G, Schäffer M, Cragg GM, Thomas DW. Anti-HIV michellamines from Ancistrocladus korupensis. J Med Chem. 1994;37(12): 1740-5.

20. Van Wyk BE. In: Nefati M, Najjaa H, Máthé A, editors. "A review of African medicinal and aromatic plants," in Medicinal and Aromatic Plants of the World: Africa, vol. 3. Dordrecht, The Netherlands: Springer; 2017. p. 19-60. 2017.

21. Elujoba AA, Odeleye OM, Ogunyemi CM. Traditional medicine development for medical and dental primary health care delivery system in Africa. Afr J Tradit Complement Altern Med. 2005;2(1):46-61.

22. Ajani EO, Sabiu S, Zakari M, Olanipekun BE, Akintunde JK, Bamisaye FA. Antioxidant capacity of fractionated extract and structural elucidation of solated compounds from leaf extract of Hydrocotyl bonariensis Comm, Exlam. J Biologically Active Prod Nat. 2017;7(3):166-77.

23. Sabiu S, Madende M, Ajao AA, Aladodo RA, Nurain IO, Ahmad JB. In: Watson RR, Preedy VR, editors. Bioactive food as dietary interventions for diabetes: the genus Allium (Amaryllidaceae: Alloideae): features, phytoconstituents, and mechanisms of antidiabetic potential of Allium cepa and Allium sativum. London: Academic Press, Elsevier; 2019. p. 137-54. ISBN: 978-0-12813822-9.

24. Torre LA, Bray F, Siegel RL, Ferlay J, Lortet-Tieulent J, Jemal A. Global cancer statistics, 2012. CA Cancer J Clin. 2015;65(2):87-108.

25. Ferlay J, Soerjomataram I, Dikshit R, Eser S, Mathers C, Rebelo M, Parkin DM, Forman D, Bray F. Cancer incidence and mortality worldwide: sources, methods and major patterns in GLOBOCAN 2012. Int J Cancer. 2015;136(5): E359-86.

26. Moten A, Schafer D, Ferrari M. Redefining global health priorities: improving cancer care in developing settings. J Glob Health. 2014;4(1).

27. Aruleba RT, Adekiya TA, Oyinloye BE, Kappo AP. Structural studies of predicted ligand binding sites and molecular docking analysis of Slc2a4 as a therapeutic target for the treatment of cancer. Int J Mol Sci. 2018;19(2):386.

28. Network CGA. Comprehensive genomic characterization of head and neck squamous cell carcinomas. Nature. 2015;517(7536):576-82.

29. Argiris A, Karamouzis MV, Raben D, Ferris RL. Head and neck cancer. Lancet. 2008;371(9625):1695-709.

30. Leemans CR, Braakhuis BJ, Brakenhoff RH. The molecular biology of head and neck cancer. Nat Rev Cancer. 2011;11(1):9-22.

31. Kutler DI, Auerbach AD, Satagopan J, Giampietro PF, Batish SD, Huvos AG, Goberdhan A, Shah JP, Singh B. High incidence of head and neck squamous cell carcinoma in patients with Fanconi anemia. Arch Otolaryngol Head Neck Surg. 2003;129(1):106-12.

32. Forastiere A, Koch W, Trotti A, Sidransky D. Head and neck cancer. N Engl J Med. 2001;345(26):1890-900.

33. Lamorde M, Tabuti JR, Obua C, Kukunda-Byobona C, Lanyero H, ByakikaKibwika P, Bbosa GS, Lubega A, Ogwal-Okeng J, Ryan M, Waako PJ. Medicinal plants used by traditional medicine practitioners for the treatment of HIV/AIDS and related conditions in Uganda. J Ethnopharmacol. 2010;130(1):43-53.

34. Ayoola GA, Coker HA, Adesegun SA, Adepoju-Bello AA, Obaweya K, Ezennia EC, Atangbayila TO. Phytochemical screening and antioxidant activities of some selected medicinal plants used for malaria therapy in southwestern Nigeria. Trop J Pharm Res. 2008;7(3):1019-24.

35. Fennell CW, Lindsey KL, McGaw LJ, Sparg SG, Stafford Gl, Elgorashi EE, Grace $\mathrm{OM}$, Van Staden J. Assessing African medicinal plants for efficacy and safety: pharmacological screening and toxicology. J Ethnopharmacol. 2004;94(2-3): 205-17.

36. Ojo OA, Afon AA, Ojo AB, Ajiboye BO, Okesola MA, Aruleba RT, Adekiya TA, Oyinloye BE. Spondias mombim L.(Anacardiaceae): chemical fingerprints, 
inhibitory activities, and molecular docking on key enzymes relevant to erectile dysfunction and Alzheimer's diseases. J Food Biochem. 2019;43(3): e12772

37. Amin AR, Kucuk O, Khuri FR, Shin DM. Perspectives for cancer prevention with natural compounds. J Clin Oncol. 2009;27(16):2712.

38. Tsuda H, Ohshima Y, Nomoto H, Fujita Kl, Matsuda E, ligo M, Takasuka N, Moore MA. Cancer prevention by natural compounds. Drug Metabol Pharmacokinet. 2004;19(4):245-63.

39. Echeverría F, Ortiz M, Valenzuela R, Videla LA. Hydroxytyrosol and Cytoprotection: A projection for clinical interventions. Int J Mol Sci. 2017; 18(5):930.

40. Moudi M, Go R, Yien CYS, Nazre M. Vinca alkaloids. Int J Prev Med. 2013; 4(11):1231.

41. Iqbal J, Abbasi BA, Mahmood T, Kanwal S, Ali B, Shah SA, Khalil AT. Plantderived anticancer agents: A green anticancer approach. Asian Pac J Trop Biomed. 2017;7(12):1129-50.

42. Safarzadeh E, Shotorbani SS, Baradaran B. Herbal medicine as inducers of apoptosis in cancer treatment. Adv Pharm Bull. 2014;4(Suppl 1):421.

43. Islam M, Iskander MN. Microtubulin binding sites as target for developing anticancer agents. Mini Rev Med Chem. 2004;4(10):1077-104.

44. Ahmed MF, Kazim SM, Ghori SS, Mehjabeen SS, Ahmed SR, Ali SM, Ibrahim M. Antidiabetic activity of Vinca rosea extracts in alloxan-induced diabetic rats. Int J Endocrinol. 2010;2010:1-7.

45. Gebbia V, Testa A, Di CG, Ingria F, Valenza R, Cannata G, Moschella F, Restivo G, Gebbia N. Vinorelbine plus cisplatin in recurrent or previously untreated unresectable squamous cell carcinoma of the head and neck. Am J Clin Oncol. 1995;18(4):293-6.

46. Budman DR. Vinorelbine (Navelbiner): A third-generation Vinca alkaloid. Cancer Investig. 1997;15(5):475-90.

47. Klement G, Baruchel S, Rak J, Man S, Clark K, Hicklin DJ, Bohlen P, Kerbel RS. Continuous low-dose therapy with vinblastine and VEGF receptor-2 antibody induces sustained tumor regression without overt toxicity. J Clin Investig. 2000;105(8):R15-24.

48. Vuddanda PR, Chakraborty S, Singh S. Berberine: a potential phytochemical with multispectrum therapeutic activities. Expert Opin Investig Drugs. 2010; 19(10):1297-307.

49. Wang N, Feng Y, Zhu M, Tsang CM, Man K, Tong Y, Tsao SW. Berberine induces autophagic cell death and mitochondrial apoptosis in liver cancer cells: the cellular mechanism. J Cell Biochem. 2010;111(6):1426-36.

50. Ho YT, Lu CC, Yang JS, Chiang JH, Li TC, Ip SW, Hsia TC, Liao CL, Lin JG, Wood WG, Chung JG. Berberine induced apoptosis via promoting the expression of caspase-8,-9 and-3, apoptosis-inducing factor and endonuclease $\mathrm{G}$ in SCC-4 human tongue squamous carcinoma cancer cells. Anticancer Res. 2009;29(10):4063-70.

51. Seo YS, Yim MJ, Kim BH, Kang KR, Lee SY, Oh JS, You JS, Kim SG, Yu SJ, Lee GJ, Kim DK. Berberine-induced anticancer activities in FaDu head and neck squamous cell carcinoma cells. Oncol Rep. 2015;34(6):3025-34.

52. Ho YT, Yang JS, Li TC, Lin JJ, Lin JG, Lai KC, Ma CY, Wood WG, Chung JG. Berberine suppresses in vitro migration and invasion of human SCC-4 tongue squamous cancer cells through the inhibitions of FAK, IKK, NF-KB, uPA and MMP-2 and-9. Cancer Lett. 2009;279(2):155-62.

53. Wang XN, Han X, Xu LN, Yin LH, Xu YW, Qi Y, Peng JY. Enhancement of apoptosis of human hepatocellular carcinoma SMMC-7721 cells through synergy of berberine and evodiamine. Phytomedicine. 2008;15:1062-8.

54. Kim DW, Ahan SH, Kim TY. Enhancement of arsenic trioxide (As2O3) mediated apoptosis using berberine in human neuroblastoma SH-SY5Y cells. J Korean Neurosurg Soc. 2007:42(5):392.

55. Youn MJ, So HS, Cho HJ, Kim HJ, Kim Y, Lee JH, Sohn JS, Kim YK, Chung SY, Park R. Berberine, a natural product, combined with cisplatin enhanced apoptosis through a mitochondria/caspase-mediated pathway in HeLa cells. Biol Pharm Bull. 2008;31(5):789-95.

56. Cragg GM, Newman DJ. Plants as a source of anti-cancer agents. J Ethnopharmacol. 2005;100(1-2):72-9.

57. Holsinger FC, Doan DD, Jasser SA, Swan EA, Greenberg JS, Schiff BA, Bekele BN, Younes MN, Bucana CD, Fidler IJ, Myers JN. Epidermal growth factor receptor blockade potentiates apoptosis mediated by paclitaxel and leads to prolonged survival in a murine model of oral cancer. Clin Cancer Res. 2003:9(8):3183-9.

58. Qin H, Luo J, Zhu YP, Xie HL, Yang WQ, Lei WB. Combination of taxanes, cisplatin and fluorouracil as induction chemotherapy for locally advanced head and neck cancer: a meta-analysis. PLoS One. 2012;7(12).
59. Taraphdar AK, Roy M, Bhattacharya RK. Natural products as inducers of apoptosis: implication for cancer therapy and prevention. Curr Sci. 2001 1387-96.

60. Aggarwal S, Takada Y, Singh S, Myers JN, Aggarwal BB. Inhibition of growth and survival of human head and neck squamous cell carcinoma cells by curcumin via modulation of nuclear factor-kB signaling. Int J Cancer. 2004; 111(5):679-92.

61. Sun Q, Prasad R, Rosenthal E, Katiyar SK. Grape seed proanthocyanidins inhibit the invasive potential of head and neck cutaneous squamous cell carcinoma cells by targeting EGFR expression and epithelial-tomesenchymal transition. BMC Complement Altern Med. 2011;11(1):134.

62. Akhtar S, Meeran SM, Katiyar N, Katiyar SK. Grape seed proanthocyanidins inhibit the growth of human non-small cell lung cancer xenografts by targeting insulin-like growth factor binding protein-3, tumor cell proliferation, and angiogenic factors. Clin Cancer Res. 2009:15(3):821-31.

63. Prasad R, Katiyar SK. Bioactive phytochemical proanthocyanidins inhibit growth of head and neck squamous cell carcinoma cells by targeting multiple signaling molecules. PLoS One. 2012;7(9):e46404.

64. Park MR, Kim SG, Cho IA, Oh D, Kang KR, Lee SY, Moon SM, Cho SS, Yoon G, Kim CS, Oh JS. Licochalcone-A induces intrinsic and extrinsic apoptosis via ERK1/2 and p38 phosphorylation-mediated TRAIL expression in head and neck squamous carcinoma FaDu cells. Food Chem Toxicol. 2015;77:34-43.

65. Lee CK, Son SH, Park KK, Park JHY, Lim SS, Kim SH, Chung WY. Licochalcone A inhibits the growth of colon carcinoma and attenuates cisplatin-induced toxicity without a loss of chemotherapeutic efficacy in mice. Basic Clin Pharmacol Toxicol. 2008;103(1):48-54

66. Cho JJ, Chae Jl, Yoon G, Kim KH, Cho JH, Cho SS, Cho YS, Shim JH. Licochalcone A, a natural chalconoid isolated from Glycyrrhiza inflata root, induces apoptosis via Sp1 and Sp1 regulatory proteins in oral squamous cell carcinoma. Int J Oncol. 2014:45(2):667-74.

67. Chang HP, Sheen LY, Lei YP. The protective role of carotenoids and polyphenols in patients with head and neck cancer. J Chin Med Assoc. 2015;78(2):89-95.

68. Drews J. Drug discovery: a historical perspective. Science. 2000;287(5460): 1960-4.

69. Hofmann A, Wang CK, Osman A, Camp D. Merging structural biology with chemical biology: structural chemistry at Eskitis. Struct Chem. 2010;21(5): 1117-29.

70. Adekiya TA, Shodehinde SA, Aruleba RT. Anti-hypercholesterolemic effect of unripe Musa paradisiaca products on hypercholesterolemia-induced rats. J Appl Pharm Sci. 2018;8(10):090-7.

71. Egbuna C, Kumar S, Ifemeje JC, Ezzat SM, Kaliyaperumal S. Phytochemicals as Lead compounds for new drug discovery. Amsterdam: Elsevier; 2019.

72. Graziose R, Ann Lila M, Raskin I. Merging traditional Chinese medicine with modern drug discovery technologies to find novel drugs and functional foods. Curr Drug Discov Technol. 2010;7(1):2-12.

73. Neergheen VS, Bahorun T, Taylor EW, Jen LS, Aruoma OI. Targeting specific cell signaling transduction pathways by dietary and medicinal phytochemicals in cancer chemoprevention. Toxicology. 2010;278(2):229-41.

74. Upadhyay S, Dixit M. Role of polyphenols and other phytochemicals on molecular signaling. Oxidative Med Cell Longev. 2015;2015.

75. Chen H, Liu RH. Potential mechanisms of action of dietary phytochemicals for cancer prevention by targeting cellular signaling transduction pathways. J Agric Food Chem. 2018;66(13):3260-76.

76. Yang HS, Kim JY, Lee JH, Lee BW, Park KH, Shim KH, Lee MK, Seo KI. Celastrol isolated from Tripterygium regelii induces apoptosis through both caspase-dependent and-independent pathways in human breast cancer cells. Food Chem Toxicol. 2011;49(2):527-32.

77. Pan Y, Meng M, Zheng N, Cao Z, Yang P, Xi X, Zhou Q. Targeting of multiple senescence-promoting genes and signaling pathways by triptonide induces complete senescence of acute myeloid leukemia cells. Biochem Pharmacol. 2017:126:34-50.

78. Tan KW, Li Y, Paxton JW, Birch NP, Scheepens A. Identification of novel dietary phytochemicals inhibiting the efflux transporter breast cancer resistance protein (BCRP/ABCG2). Food Chem. 2013;138(4):2267-74.

79. Perez M, Otero JA, Barrera B, Prieto JG, Merino G, Alvarez Al. Inhibition of ABCG2/BCRP transporter by soy isoflavones genistein and daidzein: effect on plasma and milk levels of danofloxacin in sheep. Vet J. 2013:196(2):203-8.

80. Biswas A, Clark EC, Sen CK, Gordillo GM. Phytochemical inhibition of multidrug resistance Protein-1 as a therapeutic strategy for Hemangioendothelioma. Antioxid Redox Signal. 2017;26(17):1009-19. 
81. Oyinloye BE, Adekiya TA, Aruleba RT, Ojo OA, Ajiboye BO. Structure based docking studies of GLUT4 towards exploring selected phytochemicals from Solanum xanthocarpum as a therapeutic target for the treatment of cancer. Curr Drug Discov Technol. 2019;16(4):406-16.

82. UI Qamar MT, Maryam A, Muneer I, Xing F, Ashfaq UA, Khan FA, Anwar F, Geesi MH, Khalid RR, Rauf SA, Siddiqi AR. Computational screening of medicinal plant phytochemicals to discover potent pan-serotype inhibitors against dengue virus. Sci Rep. 2019;9(1):1433.

83. Rampogu S, Park C, Ravinder D, Son M, Baek A, Zeb A, Bavi R, Kumar R, Lee G, Parate S, Pawar SC. Pharmacotherapeutics and molecular mechanism of phytochemicals in alleviating hormone-responsive breast Cancer. Oxidative Med Cell Longev. 2019;2019.

84. Hotwani K, Baliga S, Sharma K. Phytodentistry: use of medicinal plants. J Complement Integr Med. 2014;11(4):233-51.

85. Adefuye AO, Ndip RN. Phytochemical analysis and antibacterial evaluation of the ethyl acetate extract of the stem bark of Bridelia micrantha. Pharmacogn Mag. 2013;9(33):45.

\section{Publisher's Note}

Springer Nature remains neutral with regard to jurisdictional claims in published maps and institutional affiliations.

\section{Submit your manuscript to a SpringerOpen ${ }^{\circ}$ journal and benefit from:}

- Convenient online submission

- Rigorous peer review

- Open access: articles freely available online

- High visibility within the field

- Retaining the copyright to your article

Submit your next manuscript at $\boldsymbol{\wedge}$ springeropen.com 